\title{
EVALUATION OF A CITY BRAND AND ITS INFLUENCE ON TOURIST SATISFACTION
}

\author{
Paulo Ribeiro Cardoso ${ }^{a}$ \\ Alberto Ortiz Diniz
}

\begin{abstract}
The evaluation of a city, as a brand, is essential for professionals who manage the marketing and communication strategies aimed at attracting potential visitors to the location. This study investigates the applicability of an instrument for evaluating a tourist destination as a brand. The study was applied in the city of Porto, Portugal, elected best European destination in 2012, 2014 and 2017 by the International Collegiate Programming Contest (ICPC, 2020). In particular, the level of awareness, image and quality perceived by visitors to the city was assessed. The relationship between these dimensions and tourist satisfaction was also verified. Using a quantitative approach, the instrument, initially created by Konecnik and Ruzzier (2006), was adapted and applied to a convenience sample made up of young Portuguese adults who were visiting or had visited the city of Porto. The results showed that the four dimensions of the original scale had an acceptable reliability coefficient and provided relevant results about the city under study. In general, visitors expressed positive levels of "awareness", "image", "quality" and "satisfaction" in relation to the city of Porto. Variables from all three dimensions (awareness, image and quality) were detected that influenced the variables of satisfaction.
\end{abstract}

\section{KEYWORDS:}

City brand

Satisfaction

Visitors

Tourism marketing 


\section{INTRODUCTION}

The need to attract tourists and investors, while preserving the local residents, leads to competition between countries, regions and cities. In response to this challenge, public and private organizations use marketing to plan, manage and promote places, increasing their attractiveness through strategies used to position and communicate their attributes. However, to carry out the strategic planning of the marketing of a place well, it is essential to know who the consumers are. In the tourism sector, it is important to understand the visitors and potential visitors in relation to certain variables, such as awareness, image, quality and satisfaction. For this purpose, studies can be carried out with these audiences using previously developed data collection instruments. Therefore, it is essential for territorial and tourism marketing professionals to have these tools, properly assessed and tested and at their disposal.

This study had two main objectives. Firstly, and given the importance of replication studies in Marketing (Hubbard \& Armstrong, 1994; Hunter, 2001; Evanschitzky, Baumgarth, Hubbard, Raymond \& Armstrong, 2007), it sought to verify the applicability of Konecnik and Ruzzier's instrument (2006) to the study of perception in relation to the city of Porto, Portugal. It should be noted that this instrument (Konecnik and Ruzzier, 2006) had initially been used to analyse Slovenia as a tourist destination brand. Therefore, this study aimed to contribute to the development of an instrument to evaluate city brands. Secondly, this investigation involved an assessment of the city of Porto as a tourist destination. In particular, it sought to: 1 . investigate the level of awareness, image, quality and satisfaction perceived by visitors; and 2. Investigate the relationship between the dimensions of awareness, image and quality and satisfaction with the city. Using a quantitative approach, and following the instrument created by Konecnik and Ruzzier (2006), a questionnaire was administered to a convenience sample comprised of young Portuguese visitors to the city.

This study may be of interest to academics and professionals. It can provide useful information for the application of future studies in other cities or regions, in order to understand how they are perceived by tourists. Specifically, the instrument presented here can help identify variables that can influence the behavior of potential visitors to a city or place.

\section{Evaluating cities as brands}

More than ever before, cities are focusing on their brands, to project themselves to their potential visitors and improve their position in the market
(Parkerson \& Saunders, 2005; Sameh, El-Aziz \& Hefnawy, 2018). These efforts are based on the assumption that people understand cities as brands (Ashworth \& Kavaratzis, 2009; Kim \& Lee, 2018). The aims, in building a city brand, are to increase opportunities in the tourism sector and improve the image of the city, presenting it as a great place to visit, study, live, or do business (Azevedo, Magalhães \& Pereira, 2010).

When a location creates positive associations in the minds of its target consumers, this creates the conditions to build a city brand, by managing the marketing variables. Successful city brands can be attractive to tourists, new residents and investors (Paliaga, Franjic, \& StrunjePaliaga, 2010). Cities such as Manchester, Barcelona and Sydney have achieved success largely due to international events that they have hosted, which have added value and brought world recognition to the cities, causing them to become well-known and desirable (Paliaga, Franjic, \& StrunjePaliaga, 2010). Other cities have built their brands through marketing actions that include slogans, logos and communication campaigns, e.g. "Be Berlin" or "lamsterdam" (Caldwell \& Freire, 2004).

However, a city's marketing efforts should not be limited to the development of attractive slogans or the design of new logos. They should also include an analysis of the environment, a strategic perspective, and effective implementation of actions around the city (Azevedo, Magalhães \& Pereira, 2010). Many studies on local and urban marketing have focused on attributes of the city's image, such as its cultural attractions, infrastructure, climate, the welcome given by the residents, natural elements, shopping, leisure and entertainment, and safety (Chen \& Uysal, 2002; Echtner \& Ritchie, 2003). Research has also addressed the influence of these factors on consumer perception (Bigne, Sánchez \& Sánchez, 2001; Arandes, 2008).

However, in the process of building city brands, other approaches may also be needed to assess their value in relation to other locations. Konecnik and Gartner (2007) adapted the "customer-based brand equity" model for tourist destinations, which includes variables such as awareness, image, quality and loyalty.

Awareness may not result in the purchase or choice of a location as a destination but it does, at least, bring the location to the minds of potential consumers when they are considering which place to visit (Huang \& Lin, 2017). This element is addressed by Anholt (2006) in his hexagonal model of the city, being considered as "presence".

In the context of the city brand, the image is the mental representation, feelings and general perception of a certain destination (Chen \& Tsai, 2007). These representations are a set of perceptions, associations and memories that individuals process (Arandes, 2008) and that are strongly related to the identity of the place or city, with its attributes and benefits (Guerreiro, 2014). A 
positive image is related to the perceived quality and, consequently, to satisfaction (Barros, 2008).

The level of quality results from the evaluation of the services and experiences of the product. Anholt (2006) considers this element to be a prerequisite, i.e., an infrastructure related to quality-of-life. These types of factors can determine consumer satisfaction, positive word-of-mouth, and loyalty (Barros, 2008).

The last component of the model is loyalty, which is related to consumer satisfaction, as visitors can repeat the experience or recommend the location to others. Konecnik \& Gartner (2007) argue that some cities depend on repeated visits from the same visitors. This element of the brand value is also analyzed and taken into account in other empirical studies related to consumer behavior in tourism (Chen \& Tsai, 2007).

In short, a city can be evaluated based on the four dimensions presented: awareness, image, quality and satisfaction. In the empirical component of this work, we operationalize these dimensions in the evaluation of a city.

\section{MethOD}

As mentioned above, this study had two main objectives. The first was to contribute to the development of an instrument for evaluating cities as brands, verifying the applicability of the instrument created by Konecnik and Ruzzier (2006). The choice of the city of Porto as the field of investigation was relevant due to the importance the city has achieved in recent years as a tourist destination. Indeed, the city was named best European destination in 2012, 2014 and 2017 by International Collegiate Programming Contest (ICPC) (ICPC, 2020).

The second objective of this study involved an assessment of the city of Porto as a tourist destination, considering the dimensions of awareness, image, quality and satisfaction perceived by visitors. It also considered the relationship between these dimensions and tourists' satisfaction with the city.

This study used a convenience sample composed of Portuguese Millennials. This choice was justified because this generation is an important segment of the global tourism market. Millennials' desire for new experiences reinforces their desire to travel, a characteristic that makes this segment attractive to destinations aiming to increase their demand (Richards \& Morrill, 2020).

The instrument applied had previously been used to investigate the perspective of German tourists regarding Slovenia as a tourist destination brand (Konecnik \& Ruzzier, 2006). Although Slovenia is a country and Porto is a city, the characteristics analyzed in our study were relatively similar. However, some adaptations were needed, given that characteristics of a country do not entirely coincide with those of a city. For example, the variables related to the destination image were adapted, as the city of Porto does not have mountains or lakes, but it does have rivers.

This study assessed four dimensions. In the "awareness" dimension, four statements were used to measure the interviewees' opinion on recognition, recall and visualization of the city. The dimensions "image" and "quality" were based on the study by Konecnik and Ruzzier (2006) and were also used in previous studies (Baloglu \& McCleary, 1999; Gallarza, Saura \& Garcia, 2002; Echtner \& Ritchie, 2003). The dimension "satisfaction" was measured through three statements related to the tourists' overall satisfaction, intention to return, and whether they would recommend it to other people. The items of the instrument were measured using a five-point Likert scale, where 1 indicated "strongly disagree" and 5 "strongly agree". The questionnaire also included demographic issues, such as age, sex and level of education.

In the data analysis, frequencies and percentages were used in the characterization of the sample, mean and standard deviation for the descriptive analysis of the variables and Pearson's correlation was used to analyze the relationships between variables. Cronbach's Alpha test was used to analyse the internal consistency of the dimensions, and multiple regression was used to determine the influence of the three initial dimensions on the dimension "satisfaction".

\section{Results ANd Discussions}

In this chapter, the results obtained in the data analysis are presented, namely the sample characterization, the descriptive analysis of the variables and the multiple regression.

\section{Sample characteristics}

The sample consisted of 418 individuals from other regions of Portugal, who had visited the city of Porto (Table 1). In terms of sex and age, $60.8 \%$ of the respondents were female and $39.3 \%$ male, $74.6 \%$ were aged between 18 and 25 years old and $25.4 \%$ were aged between 26 and 35 years old. As regards level of education, $28.9 \%$ had completed secondary education, $43.1 \%$ had a first degree and $28.0 \%$ had a master's degree. The majority of the respondents had visited the city in the last two years (95.7\%), while the remainder (3.4\%) had visited it 3 or 4 years ago $(1.9 \%)$ or more than 5 years ago $(2.4 \%)$. 
Table 1 Demographic data of the respondents

\begin{tabular}{l|c}
\hline Demographic data & Frequency and percentage \\
\hline Sex & \\
\hline Female & $254(60.8 \%)$ \\
\hline Male & $164(39.2 \%)$ \\
\hline Age & $312(74.6 \%)$ \\
\hline $18-25$ & $106(25.4 \%)$ \\
\hline $26-35$ & \\
\hline Level of education & $121(28.9 \%)$ \\
\hline Secondary & $180(43.1 \%)$ \\
\hline Graduation & $117(28.0 \%)$ \\
\hline Postgraduate/Master & $400(95.7 \%)$ \\
\hline Last visit to Porto & $8(1.9 \%)$ \\
\hline In the last 2 years & $10(2.4 \%)$ \\
\hline 3 or 4 years ago & $418(100.0 \%)$ \\
\hline 5 years or more & \\
\hline Total &
\end{tabular}

\section{Awareness, image, quality and satisfaction among tourists}

The respondents were questioned about their level of awareness of the city of Porto (table 2). The results showed that in general, the tourists had a high level of awareness of the city, with values above the midpoint on the scale. This showed that the city, as a brand, was present in the respondents' minds. These results were better than those reported by Konecnik and Ruzzier (2006) in their analysis of Slovenia as a national brand, which is to be expected, given that the sample of that that study consisted of foreign tourists while the sample of our study consisted of national tourists who had probably had more exposure to the city of Porto, as it is the country's second largest city.

Table 2 - Variables awareness, image, quality and satisfaction in relation to Porto as a tourist destination

\begin{tabular}{|c|c|c|}
\hline Dimensions & Items & $\begin{array}{l}\text { Mean and } \\
\text { standard } \\
\text { deviation }\end{array}$ \\
\hline \multirow{4}{*}{ Awareness } & $\begin{array}{l}\text { Porto is a city that you } \\
\text { hear about. }\end{array}$ & $4.45(0.60)$ \\
\hline & $\begin{array}{l}\text { The name of the city of } \\
\text { Porto can be recogni- } \\
\text { zed among other cities. }\end{array}$ & $4.45(0.61)$ \\
\hline & $\begin{array}{l}\text { Porto is an easy city to } \\
\text { visualize in my head. }\end{array}$ & $4.13(0.89)$ \\
\hline & $\begin{array}{l}\text { Some features of the } \\
\text { city of Porto are easy } \\
\text { to remember. }\end{array}$ & $4.44(0.65)$ \\
\hline \multirow{6}{*}{ Image } & Friendly people & $3.69(0.83)$ \\
\hline & Nice weather & $3.63(0.81)$ \\
\hline & Natural beauty & $3.88(0.88)$ \\
\hline & $\begin{array}{l}\text { Beautiful banks of the } \\
\text { river }\end{array}$ & $4.45(0.64)$ \\
\hline & Relaxing atmosphere & $3.23(0.94)$ \\
\hline & $\begin{array}{l}\text { Good fun opportuni- } \\
\text { ties }\end{array}$ & $3.93(0.76)$ \\
\hline
\end{tabular}

\begin{tabular}{|c|c|c|}
\hline \multirow{8}{*}{ Image } & $\begin{array}{l}\text { Interesting historical } \\
\text { attractions }\end{array}$ & $4.22(0.63)$ \\
\hline & $\begin{array}{l}\text { Interesting cultural at- } \\
\text { tractions }\end{array}$ & $4.17(0.72)$ \\
\hline & Good beaches & $2.91(0.94)$ \\
\hline & $\begin{array}{l}\text { Good commercial faci- } \\
\text { lities }\end{array}$ & $4.16(0.64)$ \\
\hline & Exciting atmosphere & $3.44(0.81)$ \\
\hline & $\begin{array}{l}\text { Good nightlife and } \\
\text { entertainment }\end{array}$ & $3.96(0.76)$ \\
\hline & Political stability & $3.49(0.76)$ \\
\hline & Modern health facilities & $3.54(0.74)$ \\
\hline \multirow{10}{*}{ Quality } & $\begin{array}{l}\text { Low prices for tourist } \\
\text { services }\end{array}$ & $2.95(0.71)$ \\
\hline & Attractive gastronomy & $4.11(0.76)$ \\
\hline & Good value for money & $3.53(0.79)$ \\
\hline & $\begin{array}{l}\text { Good communication } \\
\text { with the local popula- } \\
\text { tion }\end{array}$ & $3.76(0.77)$ \\
\hline & Clean environment & $2.47(0.86)$ \\
\hline & Very clean spaces & $2.77(0.85)$ \\
\hline & High-quality services & $3.24(0.67)$ \\
\hline & $\begin{array}{l}\text { Good quality accom- } \\
\text { modation }\end{array}$ & $3.40(0.66)$ \\
\hline & $\begin{array}{l}\text { Sense of personal safe- } \\
\text { ty }\end{array}$ & $2.77(0.95)$ \\
\hline & Good infrastructure & $3.58(0.72)$ \\
\hline \multirow{3}{*}{ Satisfaction } & $\begin{array}{l}\text { Overall, my attitude } \\
\text { towards Porto is positi- } \\
\text { ve. }\end{array}$ & $4.18(0.71)$ \\
\hline & $\begin{array}{l}\text { Porto is a city that is } \\
\text { worth visiting again. }\end{array}$ & $4.23(0.76)$ \\
\hline & $\begin{array}{l}\text { I intend to recommend } \\
\text { Porto to friends. }\end{array}$ & $4.22(0.76)$ \\
\hline
\end{tabular}

Likert scale: 1 = strongly disagree; 5 = strongly agree

The participants were asked to rate the city's image in relation to fourteen items. The city was evaluated as having a positive image, as each item was given a score above the midpoint on the scale (table 2). This means that visitors' expectations were met (Konecnik \& Ruzzier, 2006). This is important, as positive images tend to create awareness (Konecnik \& Gartner, 2007), which can result in satisfaction with the purchase itself, intention to return, and the desire to recommend the city to others (Pike, 2002; Chen \& Tsai 2007).

The attributes of the city that obtained the highest values were "beautiful river banks", "interesting historical attractions" and "interesting cultural attractions". According to the World Tourism Organization (2008), young people like to visit popular attractions followed by visiting cultural attractions and meeting local people. This is compatible with the results of this study, in which cultural attractions were given strong positive values, and the river and its surroundings were seen as iconic locations of the city. The poorest result was for the variable "good beaches", which is understandable, as visitors seeking "sun, sea and sand" generally visit the Algarve region of Portugal.

As in the image dimension, the results for the quality 
dimension were also positive, as almost all items had scores above the midpoint on the scale (table 2). The quality attributes with the highest values were "attractive cuisine", "good communication with the local population", "good infrastructure" and "good quality-price ratio", which can be interpreted as the city's strengths. The items with the lowest values were "Very clean spaces" and "Unpolluted environment".

In the satisfaction dimension, the interviewees expressed a positive opinion about the city, to the point of stating that they would be interested in visiting it again and recommending it to their friends (table 2). This means that the visitors' expectations were met and could result in positive word-of-mouth publicity (Barros, 2008).

\section{Relationship between dimensions}

Pearson's correlation was performed to identify the relationships between the awareness, image, quality and satisfaction dimensions. Most of the dimensions showed positive and statistically significant correlations, ranging from $r=0.099(p<0.05)$ to $r=0.496(p$ $<0.05$ )

The highest value obtained was between "Exciting atmosphere" and "Intention to return" ( $r=0.496, p$ $<0.01)$. Other notable results were the relationship between "Natural beauty" and "Intention to return" ( $r=$ 0.482, $p$ <0.01); and between "Beautiful river banks" and "Intention to recommend" ( $r=0.480, p<0.01)$.

Based on the results of the Pearson's correlation, multiple regression was performed to predict the influence of variables of the awareness, image and quality dimensions on the satisfaction dimension. Thus, each of the items in the awareness, image and quality dimensions were used as independent variables, and each of the satisfaction items as dependent variables.

The analysis resulted in nine models (table 3). Each model expresses the impact of the variables of the three dimensions on each of the satisfaction variables. The image attributes had a greater influence on the satisfaction variables, representing $35.2 \%$ of overall satisfaction, $45.1 \%$ of intention to return and $42.9 \%$ of intention to recommend. These results are in agreement with other studies that suggest the influence of the image on the selection of a destination and the behavior after the visit (Qu, Kim \& Im, 2011). The variables belonging to the quality and awareness dimensions were also in line with these results, but did not produce a strong impact on the satisfaction variables, confirming that image is a central dimension in the value of the destination brand, as mentioned by Konecnik and Gartner (2007).

Some of the variables of the three dimensions (awareness, image and quality) had an impact on the three satisfaction variables. For example, "friendly peo- ple", "relaxing surroundings" and "beautiful river banks" had a relatively important impact on "overall satisfaction", "intention to return" and "intention to recommend". Also "Good communication with the local population" and "Attractive cuisine" had some impact on "Global satisfaction", "intention to visit again" and "intention to recommend".

Table 3 Multiple regression with dimension items

\begin{tabular}{|c|c|c|c|c|c|c|c|}
\hline & \multicolumn{2}{|c|}{$\begin{array}{l}\text { Overall satis- } \\
\text { faction }\end{array}$} & \multicolumn{2}{|c|}{$\begin{array}{l}\text { Intention to } \\
\text { return }\end{array}$} & \multicolumn{2}{|c|}{$\begin{array}{l}\text { Intention to } \\
\text { recommend } \\
\text { to others }\end{array}$} \\
\hline & & $\beta$ & $\begin{array}{c}\mathrm{t}- \\
\text { value }\end{array}$ & $\beta$ & $\begin{array}{c}\text { t- } \\
\text { value }\end{array}$ & $\beta$ & $\begin{array}{c}\mathrm{t}- \\
\text { value }\end{array}$ \\
\hline \multirow{4}{*}{ 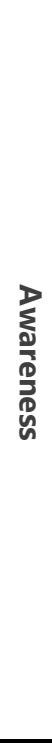 } & $\begin{array}{l}\text { Porto is } \\
\text { a city } \\
\text { that you } \\
\text { hear } \\
\text { about }\end{array}$ & 0.102 & $\underset{*}{2.096}$ & 0.170 & $\underset{* *}{3.471}$ & 0.107 & $\underset{*}{2.241}$ \\
\hline & $\begin{array}{l}\text { Porto is } \\
\text { an easy } \\
\text { city to } \\
\text { visualize } \\
\text { in my } \\
\text { head }\end{array}$ & 0.237 & $\underset{* \star}{4.357}$ & 0.109 & $\underset{*}{1.999}$ & 0.186 & $\underset{\star \star}{3.491}$ \\
\hline & \begin{tabular}{|l|} 
Some \\
features \\
of the \\
city of \\
Porto \\
are easy \\
to re- \\
member \\
\end{tabular} & 0.196 & $\underset{* *}{3.723}$ & 0.259 & $\underset{* *}{4.915}$ & 0.283 & $\underset{* \star}{5.487}$ \\
\hline & $R^{2}$ & \multicolumn{2}{|c|}{0.180} & \multicolumn{2}{|c|}{0.175} & \multicolumn{2}{|c|}{0.212} \\
\hline \multirow{10}{*}{$\begin{array}{l}\overline{3} \\
\text { ర్๊ } \\
0\end{array}$} & \begin{tabular}{|l} 
Friendly \\
people
\end{tabular} & 0.237 & $\begin{array}{c}5.460 \\
* *\end{array}$ & 0.106 & $\underset{* *}{2.633}$ & 0.206 & $\begin{array}{c}4.997 \\
\star *\end{array}$ \\
\hline & $\begin{array}{l}\text { Natural } \\
\text { beauty }\end{array}$ & & & 0.186 & $\underset{* *}{4.246}$ & 0.100 & $\underset{*}{2.244}$ \\
\hline & \begin{tabular}{|l} 
Beautiful \\
river \\
banks \\
\end{tabular} & 0.156 & $\underset{* *}{3.503}$ & 0.218 & $\underset{* *}{5.126}$ & 0.253 & $\underset{* *}{5.835}$ \\
\hline & $\begin{array}{l}\text { Relaxing } \\
\text { atmos- } \\
\text { phere }\end{array}$ & 0.110 & $\underset{* *}{2.360}$ & 0.250 & $\underset{* *}{5.857}$ & & \\
\hline & \begin{tabular}{|l|} 
Good \\
fun op- \\
portuniti \\
es \\
\end{tabular} & 0.189 & $\underset{* *}{3.863}$ & & & 0.127 & $\underset{* *}{2.740}$ \\
\hline & $\begin{array}{l}\text { Interes- } \\
\text { ting } \\
\text { histori- } \\
\text { cal at- } \\
\text { tractions }\end{array}$ & 0.095 & $\underset{*}{2.026}$ & 0.228 & $\underset{* *}{5.706}$ & 0.168 & $\underset{* *}{3.781}$ \\
\hline & $\begin{array}{l}\text { Exciting } \\
\text { atmos- } \\
\text { phere }\end{array}$ & 0.110 & $\underset{*}{2.218}$ & & & 0.162 & $\underset{* *}{3.587}$ \\
\hline & $\begin{array}{l}\text { Political } \\
\text { stability }\end{array}$ & & & 0.086 & $\underset{*}{-} \cdot \overline{322}$ & & \\
\hline & \begin{tabular}{|l|} 
Modern \\
health \\
facilities
\end{tabular} & & & & & -0.080 & $\underset{*}{-} \overline{-}$ \\
\hline & $\begin{array}{l}R^{2} \\
\end{array}$ & & & & & 0. & 20 \\
\hline
\end{tabular}




\begin{tabular}{|c|c|c|c|c|c|c|c|}
\hline & & \multicolumn{2}{|c|}{$\begin{array}{l}\text { Overall satis- } \\
\text { faction }\end{array}$} & \multicolumn{2}{|c|}{$\begin{array}{l}\text { Intention to } \\
\text { return }\end{array}$} & \multicolumn{2}{|c|}{$\begin{array}{l}\text { Intention to } \\
\text { recommend } \\
\text { to others }\end{array}$} \\
\hline & & $\beta$ & $\begin{array}{c}\mathrm{t}- \\
\text { value }\end{array}$ & $\beta$ & $\begin{array}{c}\mathrm{t}- \\
\text { value }\end{array}$ & $\beta$ & $\begin{array}{c}\mathrm{t}- \\
\text { value }\end{array}$ \\
\hline \multirow{7}{*}{ 号 } & $\begin{array}{l}\text { Attracti- } \\
\text { ve gas- } \\
\text { tronomy }\end{array}$ & 0.181 & $\underset{* *}{3.651}$ & 0.203 & $\underset{* *}{4.031}$ & 0.278 & $\underset{* *}{5.721}$ \\
\hline & $\begin{array}{l}\text { Good } \\
\text { commu- } \\
\text { nication } \\
\text { with the } \\
\text { local } \\
\text { popula- } \\
\text { tion }\end{array}$ & 0.225 & $\underset{* \star}{4.568}$ & 0.191 & $\begin{array}{c}3.847 \\
\star \star\end{array}$ & 0.250 & $\underset{* *}{5.219}$ \\
\hline & $\begin{array}{l}\text { Very } \\
\text { clean } \\
\text { spaces }\end{array}$ & & & 0.105 & $\underset{*}{2.106}$ & & \\
\hline & $\begin{array}{l}\text { High- } \\
\text { quality } \\
\text { services }\end{array}$ & 0.132 & $\underset{* \star}{2.728}$ & 0.127 & $\underset{* \star}{2.396}$ & & \\
\hline & $\begin{array}{l}\text { Good } \\
\text { quality } \\
\text { of ac- } \\
\text { commo } \\
\text { dation }\end{array}$ & & & & & 0.092 & $\underset{*}{2.021}$ \\
\hline & $\begin{array}{l}\text { Feeling } \\
\text { of per- } \\
\text { sonal } \\
\text { safety }\end{array}$ & 0.118 & $\underset{* \star}{2.477}$ & & & & \\
\hline & $R^{2}$ & & 11 & & 82 & & \\
\hline
\end{tabular}

** $p<0.01$

${ }^{*} p<0.05$

Subsequent analyses were conducted to understand the impact of awareness, image and quality on satisfaction (Table 4). First, the reliability coefficient was estimated for each dimension, with acceptable results: awareness: $\alpha=0.748$; Image: $\alpha=0.820$; Quality: $\alpha=$ 0.805; Satisfaction: $\alpha=0.858$. Next, the average values of each dimension was calculated based on the respective items. Finally, multiple regression was performed for these new variables.

The results were in agreement with the previous analysis, showing that the image had the strongest impact on satisfaction. However, the results also showed that the model explained only $47.4 \%$ of visitor satisfaction, suggesting that there are other variables that influence satisfaction. Konecnik and Gartner (2007) do not rule out the possibility that other dimensions than those presented in the model may be identified, which is in line with our results.
Table 4 - Multiple regression with the dimensions under study

\begin{tabular}{c|c|c}
\hline \multirow{2}{*}{} & \multicolumn{2}{|c}{ Satisfaction } \\
\cline { 2 - 3 } & $\beta$ & $\mathrm{t}$-value \\
\hline Awareness & $0.196^{* *}$ & 4.797 \\
\hline Image & $0.497^{* *}$ & 10.297 \\
\hline Quality & $0.117^{* *}$ & 2.664 \\
\hline$R^{2}$ & \multicolumn{2}{|c}{.474} \\
\hline${ }^{* *} \mathrm{p}<0.01$
\end{tabular}

\section{CONCLUSIONS}

This research aimed to verify the applicability of the instrument created by Konecnik and Ruzzier (2006) to evaluate a city's brand. The instrument was initially used to analyse Slovenia as a tourist destination brand, but in this work, it was applied in another geographical and cultural context: the city of Porto. The main purpose of this study is to contribute to the development of an instrument to evaluate city brand.

Using Cronbach's Alpha, it was found that the reliability coefficient of each of the four dimensions of the scale was above 0.7 , which is considered acceptable (Hair, Money, Page \& Samouel, 2007).

The secondary objectives were also achieved, i.e., to assess the city of Porto as a brand and to determine the impact of normality, image and quality on visitor satisfaction.

The results showed that in general, tourists considered the city to have a high level of awareness, proving its strong presence in the visitors' memories. This may have been a contributing factor to the city of Porto being elected best European destination in 2012, 2014 and 2017 by the International Collegiate Programming Contest (ICPC, 2020). In addition to recognizing the city's awareness, visitors considered that it had a positive image, as all items scored above the midpoint on the scale. This result demonstrates that the visitors' expectations were met. The attributes of the city with the highest values were "beautiful river banks", "interesting historical attractions" and "interesting cultural attractions". These results can help identify some aspects of the perceived positioning of the city. This will be useful for those responsible for marketing the city, for example, as it will enable them to compare the perceived image with the one they are aiming to promote.

The variables of the quality dimension showed positive values, particularly in the items "attractive cuisine" and "good communication with the local population". These results showed the visitors' perceptions in relation to some characteristics of the city. Marketing professionals must develop internal communication between hotels, restaurants, stores and other places and 
entities to ensure that this perception is maintained. They should also seek to enhance aspects such as "Very clean spaces", which achieved only moderate results in this study.

In general, visitors expressed a positive opinion about the city, to the point of stating that they would visit it again, and would recommend it to friends.

Multiple regression was used to determine whether any of the variables in the three dimensions (awareness, image and quality) influenced the satisfaction variables. It was found that the three awareness variables had an impact on the three satisfaction variables. Also, the image variables "Friendly people", "Beautiful river banks" and "Interesting historical attractions" had an impact on "Overall satisfaction", "Intention to visit again" and "Intention to recommend". Finally, the quality variables, "Attractive cuisine" and "Good communication with the local population" influenced the three satisfaction variables.

\section{Implications for professionals}

This study presents some useful contributions for professionals. It was demonstrated that all the awareness variables influenced the three satisfaction variables. In line with this result, it is recommended that city marketing communication actions be increased. These actions can be implemented through offline campaigns using the press and billboards, or using public relations to communicate with the media and publicize the attractions and interesting aspects of the city. They should also use online channels, such as the city's official website, travel blogs and social networks, which will raise awareness of the advantages of the destination among potential visitors. Regarding the content of these marketing communications, professionals should focus on four dimensions: 1) the distinctions awarded by the International Collegiate Programming Contest (ICPC), which named the city of Porto best European destination in 2012, 2014 and 2017 (ICPC, 2020 ); 2) the cultural and historical attractions and its river banks, which are UNESCO World Heritage Sites, 3) the gastronomy of the city, which also represents a cultural wealth; and finally 4) the human factor, an aspect that stood out in this investigation, as the visitors considered that Porto has friendly people who provide good communication with the visitors.

\section{Limitations and suggestions for future investiga- tions}

Despite the interest that this study may have for tourism marketing professionals, three major limitations of this work can be identified. First, due to the use of a convenience sample, there was a gap between the results obtained in this research and those that might be obtained with a probabilistic sample. Also, the sample included only young adults and as such, did not take into account the opinions of other age groups. Secondly, the Konecnik and Ruzzier scale had to be adapted for the specific characteristics of the city of Porto. Consequently, this study cannot be considered a pure replication of that research but rather, an adaptation, since there were some variables that could not be precisely compared with those of the original study. Finally, the results of this research showed the reality of only one city, making it difficult to extrapolate the results to other cities around the world.

Future studies may benefit from the use of a more comprehensive sample, covering a wider range of age groups. Comparative studies of more than one city would also be of interest, as this would help researchers discover the particularities of other cities and compare their specificities.

\section{References}

Aaker, D. (1996). Measuring Brand Equity Across Products and Markets. California Management Review, 38 (3), 102-120.

Anholt, S. (2006) The Anholt - GMI city brand index: How the world see the world's cities. Place Branding, 2 (1), 18-31.

Arandes, J. (2008). La imagen de marca de las ciudades. Provincia, 19 - enero-junio, 91-120.

Ashworth, G.; Kavaratzis, M. (2009). Beyond the logo: Brand management for cities. Brand Management, 16 (8), 520-531.

Azevedo, A.; Magalhães, D.; Pereira, J. (2010). City Marketing Myplace in XXI. Porto: Vida Económica - Editorial, S.A.

Baloglu, S.; McCleary, K. (1999). A model of destination image formation. Annals of Tourism Research, 26 (4), 868-897.

Barros, J. (2008). A satisfação com a qualidade de serviços na fidelização dos destinos turísticos: aplicada a Cabo Verde. MSc thesis, Universidade do Porto, Porto, Portugal

Bigne, J.; Sánchez, M.; Sánchez, J. (2001). Tourism image, evaluation variables and after purchase behaviour: interrelationship. Tourism Management, 22 (2001), 607-616.

Caldwell, N.; Freire, J. (2004). The difference between branding a country, a region and a city: Applying the Brand Box Model. Brand Management, 12 (1), 50-61.

Chen, C.; Tsai, D. (2007). How destination image and evaluation factors affect behavioral intentions? Tourism Management, 28, 1115-1122.

Chen, J.; Uysal, M. (2002). Market position analysis: A Hybrid Approach. Annals of Tourism Research, 29 (4), 987-1003.

Echtner, C.; Ritchie, J. (2003). The Meaning and Measurement of Destination Image. The Journal of Tourism Studies, 14 (1), 37-48. 
Evanschitzky, H.; Baumgarth, C.; Hubbard, R.; Armstrong, S. (2007).Replication Research in Marketing Revisited: A Note on a Disturbing Trend. Journal of Business Research, 60 (4), 411-415.

Gallarza, M., Saura, I.; García, H. (2002). Destination image: Towards a Conceptual Framework. Annals of Tourism Research, 29 (1), 56-78.

Guerreiro, M. (2014) O Papel da Cultura na Gestão da Marca das Cidades. Caderno Profissional de Marketing - UNIMEP, 2 (1), 1-11.

Hair, J.; Money, A.; Page, M.; Samouel, P. (2007). Research Methods for Business, West Sussex, England: John Wiley \& Sons.

Huang, S.; Lin, L. (2017). Awareness Effects of the Tourism Slogans of Ten Destinations in Asia. Journal of China Tourism Research, 13(2):1-13.

Hubbard, R.; Armstrong, S. (1994). Replications and Extensions in Marketing - Rarely Published But Quite Contrary. International Journal of Research in Marketing, 11, 233-248.

Hunter, J. (2001). The desperate need for replications. Journal of Consumer Research, Jun 2001, 28 (1), 149-158.

ICPC (2020). Porto Best European Destination. Available in: https://icpc2019.up.pt/2018/09/20/news-2/index.html

Kim, H.; Lee, T. (2018). Brand Equity of a Tourist Destination. Sustainability, 10, 2-21.

Konecnik M.; Gartner, W. (2007). Customer-based brand equity for a destination. Annals of Tourism Research, 34 (2), 400-421.

Konecnik M.; Ruzzier, M. (2006). The Influence of Previous Visitation on Customer's Evaluation of a Tourism Destination. Managing Global Transition, 4(2), 145-165.

Pakerson, B.; Saunders, J. (2005). City branding: Can goods and services branding models be used to brand cities? Place Branding and Public Diplomacy, 1 (3), 242-264.

Paliaga, M.; Franjic, Z,; Strunje, Z. (2010). Methodology of valuation of cities' brands. Ekonomska istrazivanja, 23 (2), 102 111.

Pike, S. (2002). Destination image Analysis: A Review of 142 Papers from 1973-2000. Tourism Management, 23(5), 541-549.

Qu, H., Kim, L.; Im, H. (2011). A model of destination branding: Integrating the concepts pf the branding and destination image. Tourism Management, 32(3), 465-476.

Richards, G.; Morrill, W. (2020). Motivations of global Millennial travelers. Revista Brasileira de Pesquisa em Turismo, 14(1): 126-135.

Sameh, H.; El-Aziz, H.; Hefnawy, N. (2018). Building a successful city branding case study: Dubai. Journal of Al Azhar University Engineering Sector, 13(48), pp.1058-1065.

World Tourism Organization (2008), Youth Travel Matters - Understanding the Global Phenomenon of Youth Travel, Madrid: World Tourism Organization. 